\title{
PENGEMBANGAN SISTEM INFORMASI PEMBIAYAAN (STUDI KASUS: BAGIAN CUSTODY BANK RAKYAT INDONESIA SYARIAH)
}

\author{
Nia Kumaladewi *1 \\ Department of Information Systems Faculty of Science and Technology \\ ${ }^{*}$ Syarif Hidayatullah State Islamic University Jakarta \\ Jl. Ir. H. Juanda No. 95, Ciputat, INDONESIA \\ E-mail:nia_april12@yahoo.com ${ }^{l}$
}

\begin{abstract}
Abstract - BRI Syariah merupakan salah satu lembaga keuangan syariah yang usaha pokoknya memberikan pembiayaan dan jasa-jasa lainnya dalam lalu lintas pembayaran serta peredaran uang yang pengoperasiannya disesuaikan dengan prinsip syariah Islam. Saat dilakukan penelitian, pencatatan dan pengelolaan data Safe Keeping/Jaminan dan pembiayaan pada bagian custody masih dilakukan secara manual sehingga memungkinkan terjadinya kesalahan pencatatan data. Penelitian ini berusaha membangun system informasi yang terintegrasi untuk mengelola data safe keeping dan file pembiayaan dengan menggunakan metode pengembangan RAD (Rapid Application Development) dan tool Unified Modelling Language (UML). Sistem ini dapat menyajikan informasi safe keeping/jaminan dan pembiayaan untuk bagian Custody dan Financing Support Manager. Berdasarkan hasil pengujian, dapat disimpulkan bahwa sistem informasi telah berjalan sesuai tujuan pembuatannya.
\end{abstract}

Keywords : Bank BRI Syariah, Safe Keeping/Jaminan dan Pembiayaan

\section{PENDAHULUAN}

\subsection{Latar Belakang}

Dunia informasi dan telekomunikasi telah memasuki era baru. Pada saat ini kebutuhan seseorang akan data dan informasi sangatlah tinggi. Pada saat ini pendataan dan pengolahan informasi dituntut untuk dapat lebih cepat sampai kepada pihak-pihak yang membutuhkan. Beberapa menit pun dapat terjadi perubahan pada data dan informasi. Perubahan tersebut akan sangat berpengaruh kepada seseorang dalam mengambil keputusan dan menentukan kebijakan.

Dengan perkembangan teknologi yang sudah ada saat ini dapat memudahkan penyelesaian tugas yang lebih akurat. Pengetahuan konsep basis data muncul dan mulai berkembang seiring dengan adanya kebutuhan pengolahan data untuk memenuhi kebutuhan informasi. Saat ini aplikasi basis data telah dipergunakan oleh hampir seluruh bidang kehidupan manusia, seperti dalam proses bisnis manajemen, perbankan, manufaktur, pariwisata maupun dalam bidang pendidikan. Basis data sebagai sebuah bagian penting dalam sebuah sistem informasi, memiliki berbagai peran penting mulai dari penyusunan sistem informasi hingga menjadi sebuah sumber informasi (Sutanta, Edhy 2011).
Bank Rakyat Indonesia (BRI) Syariah merupakan salah satu lembaga keuangan syariah. BRI Syariah hadir mempersembahkan sebuah bank ritel modern terkemuka dengan layanan finansial sesuai kebutuhan nasabah dengan jangkauan termudah untuk kehidupan lebih bermakna. Selama melakukan praktek kerja lapangan disana saya di tempatkan dalam divisi Financing Support bagian custody yang diberi tugas untuk membantu pengelolaan terkait data agunan / jaminan (safe keeping) dan file pembiayaan. Unit kerja custody bertugas mengelola penyimpanan yang berhubungan dengan penerimaan, pencatatan dan penyimpanan dokumen hukum yaitu agunan / jaminan (safe keeping) dan dokumen pembiayaan yang mendapatkan fasilitas pembiayaan bank (debitur).

Pada saat dilakukan penelitian pengelolaan data jaminan/ safe keeping dan dokumen pembiayaan masih dilakukan manual dengan menggunakan aplikasi Open Office sehingga sering bermasalah dengan kecepatan dan ketepatan dalam pemrosesan data. Dari uraian singkat di atas sangat menarik untuk melakukan penelitian dan pembuatan Sistem Informasi pengeloalaan data jaminan/safe keeping dan pembiayaan pada Bagian Custody Berbasis Web PHP dan MySQL. Serta memberikan solusi untuk menangani 
permasalahan tersebut dengan cara memberikan suatu usulan rancangan Sistem Informasi dangan tema: "Pengembangan Sistem Informasi Pembiayaan (Studi Kasus: Bagian Custody Bank Rakyat Indonesia Syariah)".

\subsection{Identifikasi Masalah}

Identifikasi masalah adalah sebagai berikut:

1) Banyaknya data safe keeping/jaminan dan file pembiayaan berupa dokumen hukum yang di kelola oleh unit kerja custody tidak di dukung dengan teknologi yang baik, sehingga masih dikelola dengan manual yang memungkinkan terjadinya kesalahan dan berisiko untuk BRI Syariah.

2) Kebutuhan akan sebuah sistem yang dapat memudahkan dalam penyimpanan dan pengolahan data safe keeping dan pembiayaan sehingga dapat meningkatkan kinerja unit kerja custody.

\subsection{Rumusan Masalah}

Adapun rumusan masalah adalah sebagai berikut: Bagaimana merancang bangun sistem informasi pengolahan data safe keeping dan file pembiayaan agar memudahkan pengguna dalam pengambilan kembali data?

\subsection{Batasan Masalah}

Batasan masalah dari penelitian adalah sebagai berikut:

1) Membangun sistem informasi safe keeping dan pembiayaan di bagian custody pada BRI Syariah.

2) Sistem yang dibuat hanya dapat di akses oleh unit kerja Custody dan Financi Support Manager BRI Syariah.

3) Penelitian ini dilakukan sampai tahap implementasi yaitu pengkodean dan testing dan tidak termasuk perawatan sistem (maintenance).

4) Metodologi pengembangan sistem yang digunakan adalah Object Oriented Analisis Desain dengan Rapid Application Development (RAD) yang terdiri dari Permulaan Sistem, Analisis Sistem, Desain Sistem dan Implementasi Sistem. Pada tahap implementasi penulis hanya membahas sampai proses testing.

5) Bahasa pemrograman yang digunakan adalah XAMPP dan basis data yang digunakan adalah MySQL.

\subsection{Tujuan Penelitian}

Penelitian ini bertujuan untuk: memberikan usulan kepada Bagian Custody BRI Syariah dalam merancang dan membangun sebuah Sistem Informasi yang dapat memberikan akses mudah bagian Custody untuk mengelola data safe keeping dan file pembiayaan.

\section{KERANGKA TEORI}

\subsection{Pengertian Custody}

Custody berasal dari kata custodian yang berati penjaga. Unit kerja custody bertugas mengelola penyimpanan yang berhubungan dengan penerimaan, pencatatan dan penyimpanan dokumen hukum dan dokumen pembiayaan nasabah yang mendapatkan fasilitas pembiayaan bank (debitur). Dasar peraturan Undang-undang RI No. 8 Tahun 1997 tentang Dokumen Perusahaan.

\subsection{Pengertian Safe Keeping}

Safe keeping mengandung arti agunan/ jaminan yaitu dokumen hukum yang timbul karena adanya perjanjian atas perikatan antara nasabah/ penjamin dengan bank, maupun seluruh bentuk kepemilikan agunan. Jaminan mengandung arti sebagai kepercayaan/ keyakinan dari bank atas kemampuan atau kesanggupan debitur untuk melaksanakan kewajibannya. Sedangkan agunan diartikan sebagai barang/ benda yang dijadikan jaminan untuk melunasi utang nasabah debitur. Pengertian jaminan terdapat dalam SK Direksi Bank Indonesia NO. 23/69/KEP/DIR tanggal 28 februari 1991, yaitu: "Suatu keyakinan kreditur bank atas kesanggupan debitur untuk melunasi kredit sesuai dengan yang diperjanjijkan". Sedangkan pengertian agunan diatur dalam Pasal 1 angka 23 UU No. 10 Tahun 1998, yaitu: "Jaminan pokok yang diserahkan debitur dalam rangka pemberian fasilitas kredit atau pembiayaan berdasarkan Prinsip Syariah, sesuai dengan ketentuan yang ditetapkan oleh Bank Indonesia”.

Agunan/ jaminan (Safe Keeping), terdiri atas:

1) Asli dokumen jaminan yaitu (Sertifikat, Bilyet Deposito, Girik, BPKB, SIPTU, SIPTB, dan lain-lain).

2) Dokumen pendukung jaminan yaitu (IMB, STTS dan SPPT, PBB, AJB, kwitansi kosong bermaterai, faktur, dan lain-lain).

3) Covernote akad jaminan dan atau pembiayaan.

4) Tanda terima jaminan.

5) Asli surat konfirmasi penutupan asuransi/ polis asuransi (jika sudah selesai). 


\subsection{Pengertian File Pembiayaan}

Pengertian Pembiayaan terdapat dalam SK Direksi Bank Indonesia No. 31 / 147 / KEP / DIR Pasal 14 ayat 3 tanggal 12 November 1998 dan pada UU No. 7 Tahun 1992 Tentang Perbankan Pasal 1 angka 12, yaitu: "Pembiayan berdasarkan Prinsip Syariah adalah penyediaan uang atau tagihan yang dipersamakan dengan itu berdasarkan persetujuan atau kesepakatan antara Bank dengan pihak lain yang mewajibkan pihak yang dibiayai untuk mengembalikan uang atau tagihan tersebut setelah jangka waktu tertentu dengan imbalan atau bagi hasil".

File Pembiayaan/ dokumen pembiayaan bersifat administratif dan pendukung dari dokumen hukum terkait panyaluran pembiayaan kepada nasabah oleh bank. Dokumen pembiayaan merupakan media administratif mengenai proses pemberian pembiayaan dan bukan untuk menyimpan hal yang berkaitan dengan transaksi pembiayaan.

File pembiayaan, antara lain terdiri atas :

1) Dokumen perizinan

2) Dokumen identitas nasabah

3) Dokumen yang berkaitan dengan peraturan pemerintah/ Undang-undang.

4) Dokumen administrasi lainnya berkaitan dengan penarikan pembiyaan.

\subsection{Metode Pengembangan Sistem}

Rapid Application Development (RAD) merupakan salah satu metode prototyping yang memiliki tahapan-tahapan berikut (Kendall, 2008):

1) Perencanaan Syarat-syarat

Dalam fase ini pengguna dan penganilisis bertemu untuk mengidentifikasi tujuan-tujuan aplikasi atau sistem serta mengidentifikasi syarat-syarat informasi yang ditimbulkan dari tujuan-tujuan tersebut. Orientasi dalam fase ini ialah menyelesaikan masalah-masalah perusahaan. Meskipun teknologi informasi dan sistem bisa mengarahkan sebagian dari sistem yang diajukan, fokusnya akan selalu tetap pada upaya pencapaian tujuan

2) Workshop Design

Fase ini adalah fase untuk merancang dan memperbaiki yang dapat digambarkan sebagai workshop. Selama workshop design RAD, pengguna merespon working prototype yang ada dan menganalisa, memperbaiki modulmodul yang dirancang menggunakan perangkat lunak berdasarkan respon pengguna.

3) Fase Implementasi
Analyst bekerja secara intens dengan pengguna selama workshop design untuk merancang aspek-aspek bisnis dan non-teknis dari proses bisnis yang ada. Segera setelah aspek-aspek ini disetujui dan sistem dibangun dan di-sharing, sub-sub sistem di ujicoba dan diperkenalkan kepada stakeholder.

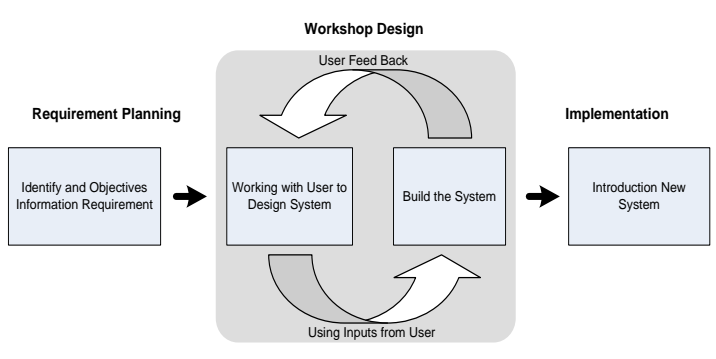

Gambar 1. Tahapan RAD (Kendall, 2008)

Menurut Kendall \& Kendall (2008), model RAD memiliki keuntungan sebagai berikut :

1) Dapat mempersingkat waktu yang biasanya diperlukan dalam SHPS (Siklus Hidup Pengembangan Sistem) tradisional antara perancangan dan penerapan sistem informasi.

2) Pengembangan aplikasi cepat dapat digunakan sebagai perangkat yang tajam dan dimaksudkan untuk memperbaharui, meningkatkan dan menyeleksi bagian-bagian terpilih dari suatu sistem.

\subsection{Object Oriented Analysis and Design (OOAD)}

Object-Oriented Analysis adalah metode analisa yang memeriksa requirement (syarat/keperluan yang harus dipenuhi suatu sistem) dari sudut pandang kelas-kelas dan objekobjek yang ditemui dalam ruang lingkup permasalahan. Sedangkan Object-Oriented Design adalah metode untuk mengarahkan arsitektur software yang didasarkan pada manipulasi objek-objek sistem atau subsistem (Suhendar, 2002).

\section{Encapsulation}

Encapsulation adalah proses menyembunyikan detil implementasi sebuah objek. Satu-satunya jalan untuk mengakses data objek tersebut adalah melalui interface. Interface melindungi internal state sebuah objek dari "campur tangan" pihak luar. Oleh karena itu objek sering digambarkan sebagai kotak hitam (black box) yang menerima dan mengirim pesan-pesan (messages). Dalam object-oriented programming kotak hitam tersebut berisi kode (himpunan intruksi dengan bahasa yang dipahami komputer) 
dan data (informasi dimana intruksi tersebut beroperasi dengannya).

Dalam object-oriented programming, kode dan data disatukan dalam sebuah "benda" yang tersembunyi isinya, yaitu objek. Pengguna objek tidak perlu tahu isi dalam kotak tersebut. Untuk dapat berkomunikasi dengan objek, diperlukan pesan (message). Secara formal message di definisikan sebagai permintaan untuk objek penerima (receiver object) untuk membawa metode yang ditunjukan atau perilaku dan mengembalikan result dari aksi tersebut kepada objek pengirim (sender object) (Suhendar, 2002).

\section{Association dan Aggregation}

Association (asosiasi) adalah hubungan antar objek yang saling membutuhkan. Sedangkan aggregation (agregasi) adalah bentuk khusus dari asosiasi yang menggambarkan seluruh bagian suatu objek merupakan bagian dari objek lainnya. Sebagai contoh, objek tanggal dapat disusun dari objek hari, objek bulan, dan objek tahun (Suhendar, 2002).

\subsection{UML (Unified Modelling Language)}

UML (Unified Modeling Language) adalah salah satu alat bantu yang sangat handal di dunia pengembangan sistem yang berorientasi objek. Hal ini dikarenakan UML menyediakan bahasa pemodelan visual yang memungkinkan bagi pengembang sistem untuk membuat cetak biru atas visi mereka dalam bentuk yang baku, mudah dimengerti serta dilengkapi dengan mekanisme yang efektif untuk berbagi (sharing) dan mengkomunikasikan rancangan mereka dengan yang lain (Munawar, 2005).

\section{METODE PENELITIAN}

\subsection{Metode Pengumpulan Data}

Dalam mengumpulkan data untuk pengembangan sistem ini dilakukan dengan cara :

\section{a. Observasi}

Hal yang dilakukan penulis adalah mengumpulkan data dan informasi yaitu dengan cara meninjau dan melakukan pengamatan secara langsung ke BRI Syariah guna memperoleh data yang dibutuhkan. Pengamatan dilakukan pada: Bagian Custody BRI Syariah Cabang BSD City Tangerang yang beralamatkan Jalan Pahlawan Seribu Ruko Tol Boulevard Blok B10-12 BSD City, Tangerang Selatan. Berdasarkan pengamatan yang penulis lakukan, penulis mengumpulkan informasi mengenai:

1) Profil BRI Syariah.

2) Sistem Berjalan.
Memuat tentang sistem dan prosedur berjalan.

3) Data Safe Keeping dan File Pembiayaan.

Memuat tentang data-data yang dibutuhkan untuk mengimplementasikan sistem.

\section{b. Wawancara}

Wawancara dilakukan dengan pihak yang terkait dengan masalah pengelolaan data safe keeping dan pembiayaan untuk mengetahui masalah-masalah yang menjadi kendala. Data hasil wawancara digunakan untuk mengidentifikasi kebutuhan-kebutuhan pengguna akan sistem informasi. Wawancara dilakukan pada bulan April 2012 dengan narasumber Bapak Reza Nizar selaku unit kerja Custody yang berada di bawah pengawasan Bapak Novian Yudit Ardita selaku Financing Support Manager dari BRI Syariah Kantor Cabang BSD City

\section{c. Studi Pustaka}

Metode ini digunakan untuk mempelajari literature sejenis yang terkait dengan penelitian.

\subsection{Metode Pembuatan Sistem}

Dalam pembuatan Sistem Informasi ini, dengan menggunakan metodologi Rapid Application Development (Kendall, 2008). Tahap-tahap pengembangan yang dilakukan, yaitu:

a) Perencanaan Syarat-Syarat

b) Workshop Design

c) Fase Implementasi

\section{KERANGKA PENELITIAN}

Dalam melakukan penelitian ini, peneliti melakukan tahapan-tahapan kegiatan dengan mengikuti rencana kegiatan yang tertuang dalam kerangka penelitian meliputi metode pengumpulan data dan metode pengembangan sistem. Berikut ini dapat dilihat gambaran kerangka berpikir penelitian. 


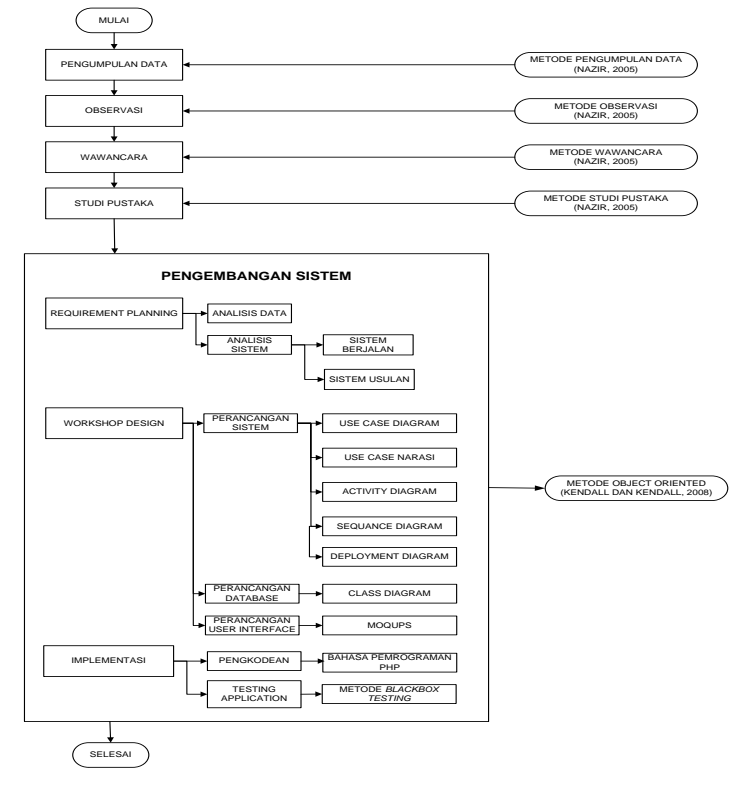

Gambar 1. Kerangka Penelitian

\section{HASIL DAN PEMBAHASAN}

\subsection{Perencanaan Syarat-Syarat}

\section{a. Analisis Data}

Saat dilakukan penelitian pada BRI Syariah Bagian Custody mengelola 2 (dua) data yaitu data Safe Keeping dan file pembiayaan. Data Safe Keeping mengandung arti agunan/ jaminan yaitu dokumen hukum yang timbul karena adanya perjanjian atas perikatan antara nasabah/ penjamin dengan bank, maupun seluruh bentuk kepemilikan agunan. Data Safe Keeping/ jaminan yang akan di lakukan pencatatan oleh bagian custody meliputi: nama nasabah, account officer, segmentasi, unit, plafond, jaminan, jatuh tempo, IMB, asuransi kebakaran dan asuransi jiwa. File Pembiayaan/ dokumen pembiayaan adalah dokumen yang bersifat administratif dan pendukung dari dokumen hukum terkait panyaluran pembiayaan kepada nasabah oleh bank. File pembiayaan yang akan dilakukan pencatatan oleh bagian custody meliputi: nama nasabah, account officer, segmentasi, unit, plafond, angsuran, tenor dan tanggal pencairan.

\section{b. Analisis Sistem Berjalan}

Custody menginput data safe keeping/ jaminan dan file pembiayaan setelah menerima berkas jaminan dan pembiayaan nasabah dari bagian financing administration. Kemudian custody memberikan laporan bulanan kepada Financing Support Manager dengan mencetak terlebih dahulu kemudian diberikan hardcopy untuk dilakukan stock poname yaitu pembaruan data dengan mencocokkan antara data yang telah diinput dengan real dokumen yang tersimpan diruang penyimpanan/ rumah pemberkasan

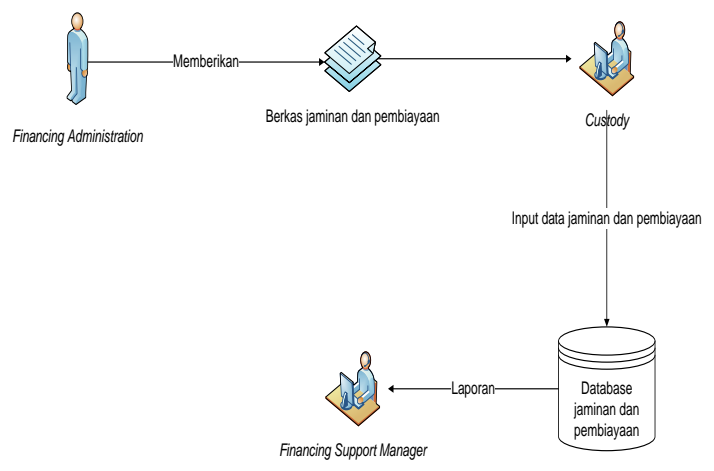

Gambar 2. Rich Picture Sistem Berjalan

\section{c. Analisis Sistem Usulan}

Financing administration memberikan berkas jaminan dan pembiayaan ke bagian custody. Kemudian custody sebagai admin melakukan login pada sistem safe keeping/jaminan dan file pembiayaan. Setelah login custody dapat mengelola data jaminan dan pembiayaan yang telah terbagi. Custody dapat menginput data jaminan, update data jaminan, search data jaminan. Custody dapat menginput data pembiayaan, update data pembiayaan, search data pembiayaan sehingga pekerjaan tersebut dapat dilakukan dengan cepat dan tepat. Dalam sistem safe keeping dan file pembiayaan ada menu cetak data yaitu cetak data jaminan dan pembiayaan untuk pelaporan ke Financing Support Manager. Financing Support Manager dapat langsung mengakses laporan dari custody melalui sistem dengan login terlebih dahulu sebagai user yang hanya bisa melihat data jaminan dan pembiayaan juga mencetaknya.

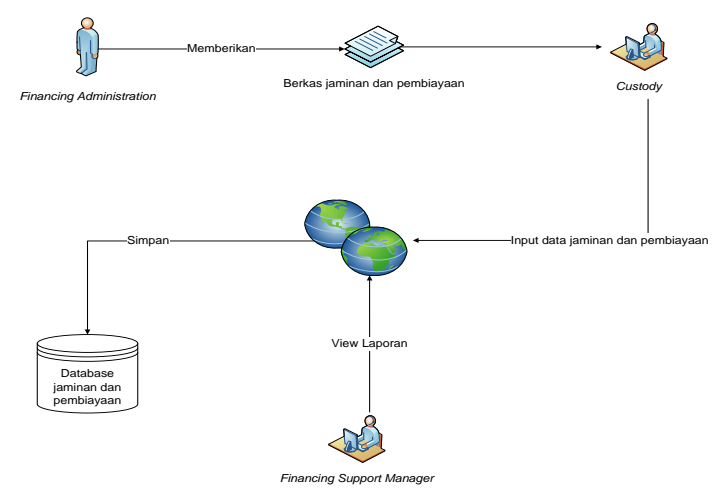

Gambar 3. Rich Picture Sistem Usulan 


\subsection{Workshop Desain}

Pada tahap ini dilakukan perancangan sistem, perancangan basis data, dan perancangan antar muka sistem.

\section{a) Perancangan Sistem}

Alur proses pendaftaran digambarkan dengan menggunakan diagram UML yang terdiri atas use case diagram, activity diagram dan sequence diagram.

Use Case Diagram

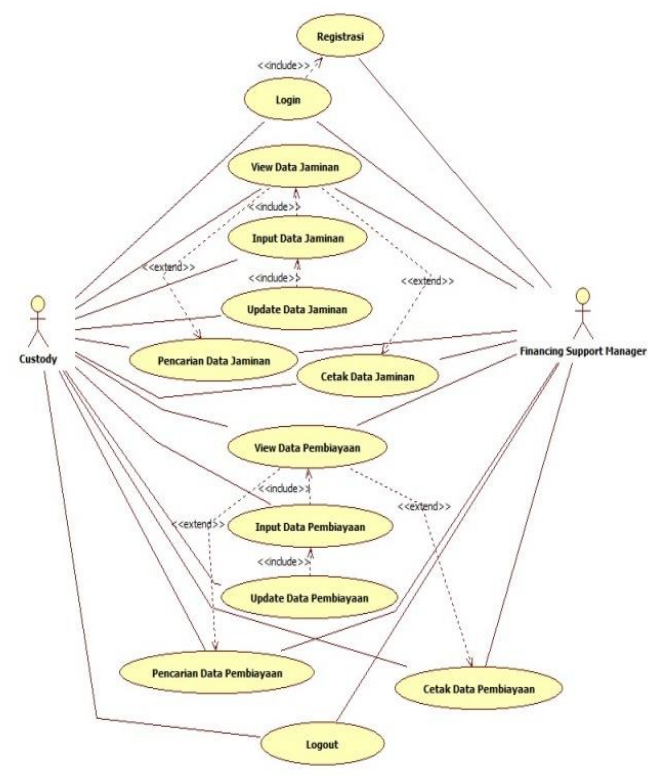

Gambar 4. Use case Diagram

Activity Diagram Input Data Jaminan

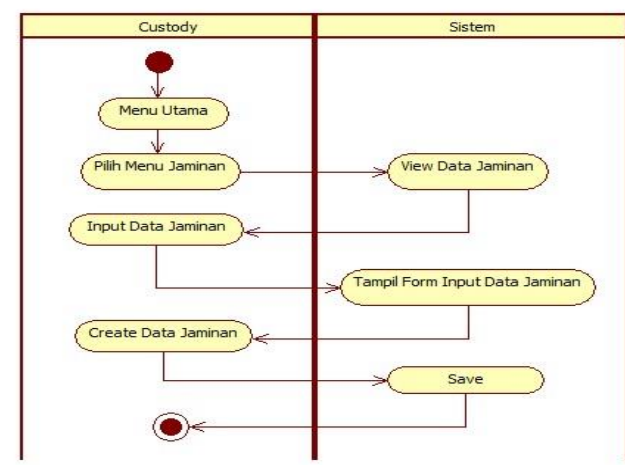

Gambar 5. Activity Diagram Input Data Jaminan
Activity Diagram Input Data Pembiayaan

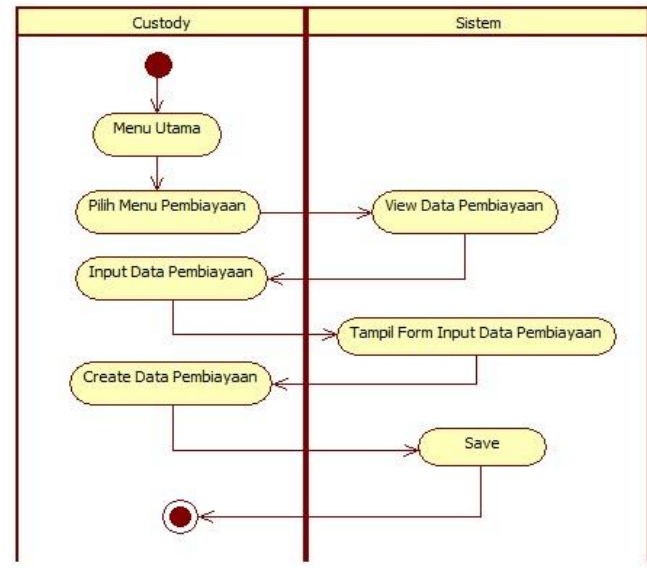

Gambar 6.Activity Diagram Input Data Pembiayaan

Sequence Diagram Kelola Data Jaminan

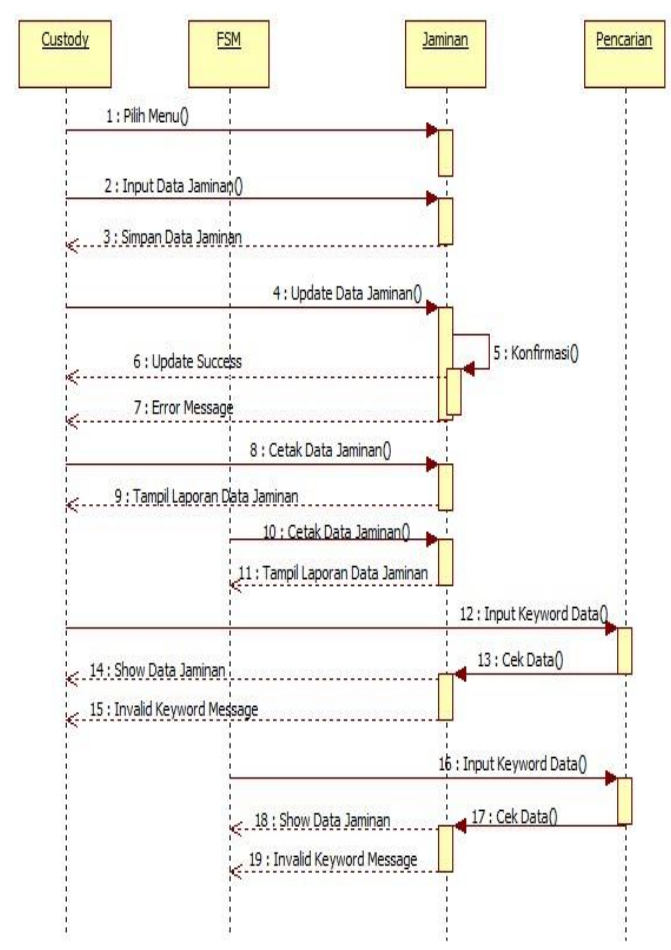

Gambar 7. Sequence Diagram Kelola Data Jaminan 
Sequence Diagram Kelola Data Pembiayaan

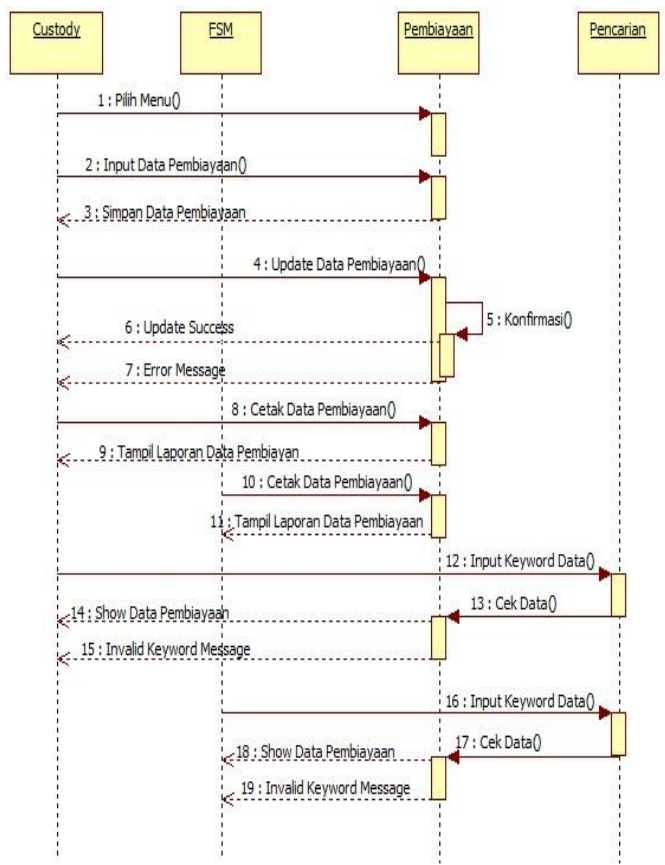

Gambar 8. Sequence Diagram Kelola Data Pembiayaan

\section{b) Perancangan Basis Data}

Berikut gambar 9. Class Diagram dari Sistem Informasi Safe Keeping dan Pembiayaan.

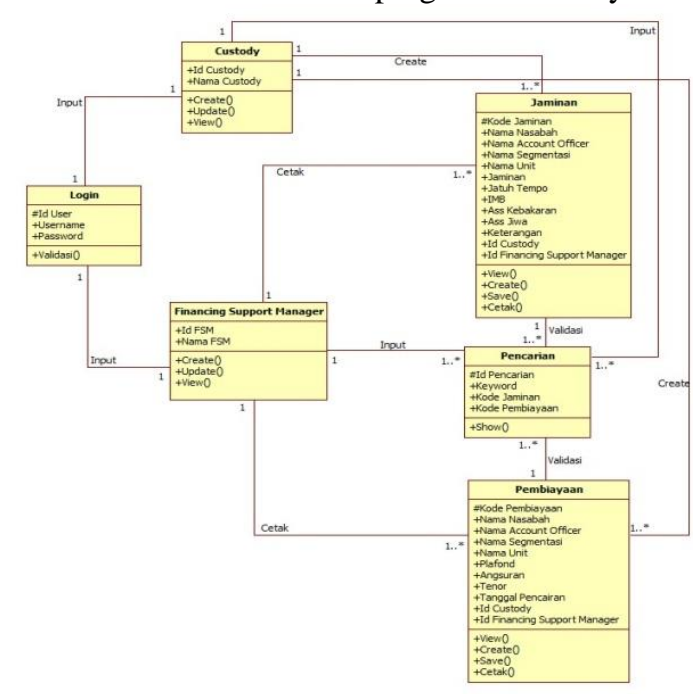

Gambar 9. Class Diagram

\section{c) Perancangan Antar Muka Sistem}

Antar Muka Sistem ini bertujuan untuk menggambarkan rancangan tampilan aplikasi yang akan dibuat. Perancangan layout terdiri dari modul:

1) Account Custody

Account custody dapat melakukan seluruh aktivitas dalam sistem karena berperan sebagai administrator sistem. Custody dapat melakukan seluruh kegiatan dalam sistem yaitu: kegiatan input, view, edit, delete, pencarian dan cetak data baik pada menu jaminan dan pembiayaan apabila sudah melakukan aktivitas login sistem terlebih dahulu. Perbedaan pada aktor Financing Support Manager (FSM) yaitu aktor custody dapat melakukan kegiatan input, edit dan delete data baik pada menu jaminan dan pembiayaan.

2) Account Financing Support Manager (FSM)

Account Financing Support Manager (FSM) sebagai user sistem yang dapat melakukan kegiatan view, pencarian dan cetak data baik pada menu jaminan dan pembiayaan apabila sudah melakukan aktivitas login sistem terlebih dahulu.

\subsection{Fase Implementasi}

a) Pembuatan Sistem Informasi Safe Keeping dan Pembiayaan

Pada proses pembuatan sistem informasi ini, penulis menggunakan XAMPP versi 1.6.2 yang mencakup: Apache versi 2.2.4 untuk web server, PHP versi 5.2.2 untuk bahasa pemrograman dan MySQL versi 5.0.41 untuk database-nya. Selain itu, penulis juga menggunakan Edit Plus 2 dan Macromedia Dreamweaver MX 2004 sebagai software editor dan Adobe Photoshop 7.0 untuk mengolah gambar.

Berikut ini spesifikasi minimal hardware dan software yang digunakan:

a. Perangkat Keras (Hardware)

1. Server:

a. Processor Intel Pentium $42.8 \mathrm{GHz}$

b. $256 \mathrm{MB}$ of $R A M$

c. Harddisk $80 \mathrm{~GB}$

2. Client:
a. Processor Intel Pentium $42.8 \mathrm{GHz}$
b. $256 \mathrm{MB}$ of $R A M$
c. Printer tinta

b. Perangkat Lunak (Software)

1. Server:

a. Microsoft Windows XP Professional Version 2002 Service Pack 2

b. XAMPP version 1.6.2 yang mencakup: Apache version 2.2.4, PHP version 5.2.2, dan MySQL version 5.0.41

c. Browser: Microsoft Internet Explorer Version: 6.0

2. Client 
a. Microsoft Windows XP Professional Version 2002 Service Pack 2

b. Browser: Microsoft Internet Explorer Version: 6.0

\section{b) Pengujian Sistem}

Setiap program menjalani pengujian secara pribadi untuk memastikan bahwa program yang telah kita buat bisa bebas dari kesalahan (bug), walaupun tidak menutup kemungkinan masih terjadi sedikit bug atau tidak $100 \%$ bebas dari bug, namun pengujian ini setidaknya bisa meminimalisasi kesalahan yang akan terjadi.

Pada tahap ini, menggunakan metode pengujian unit dengan pendekatan black-box testing.

Pengujian dengan Black-box testing yang dilakukan untuk memperlihatkan bahwa fungsifungsi bekerja dengan baik dalam arti masukan yang diterima dengan benar dan keluaran yang dihasilkan benar-benar tepat,

pengintegrasian dari eksternal data berjalan dengan baik. Cara pengujian yang dilakukan dengan menjalankan sistem informasi safe keeping dan pembiayaan dan melakukan input data serta melihat output-nya apakah sesuai dengan proses yang diharapkan.

\section{c) Display Hasil}

1. Menu Home untuk Account Custody dan Financing Support Manager

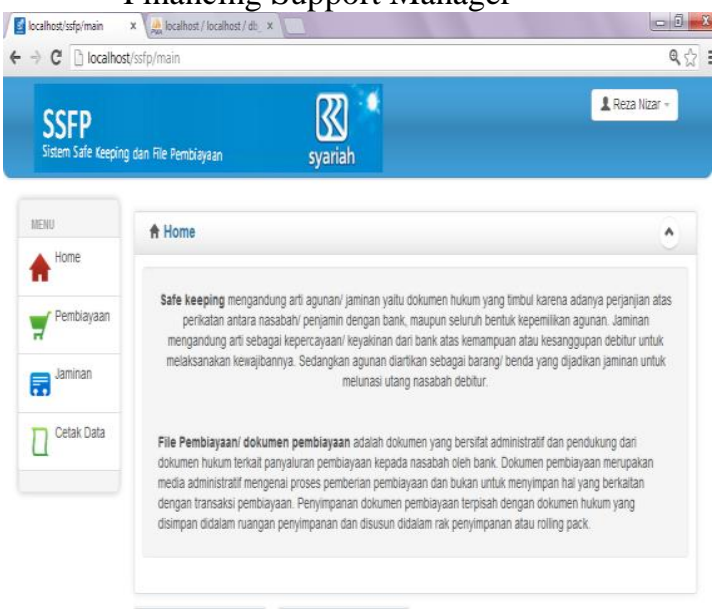

Gambar 10. Menu Home

2. Menu Pembiayaan untuk Account Custody
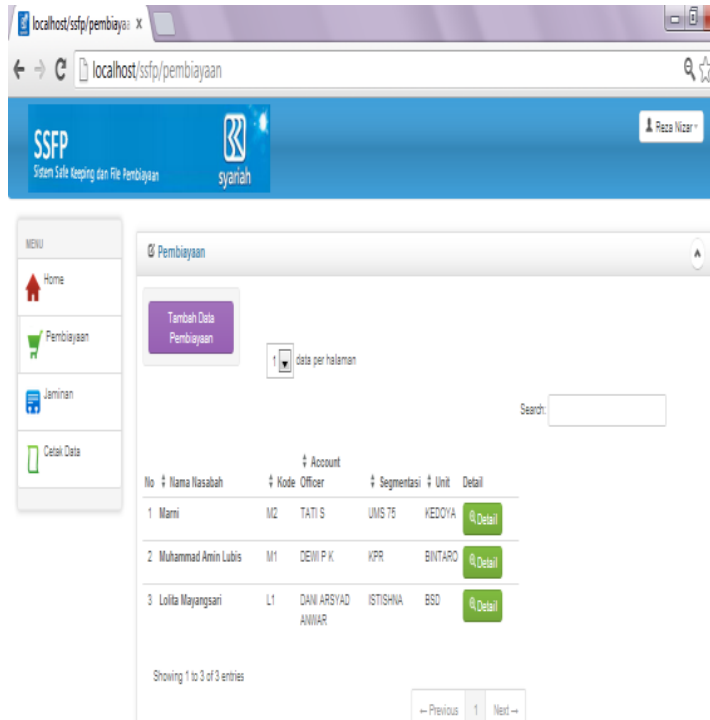

Gambar 11 Menu Pembiayaan untuk Account Custody

3. Menu Jaminan pada Account Financing Support Manager

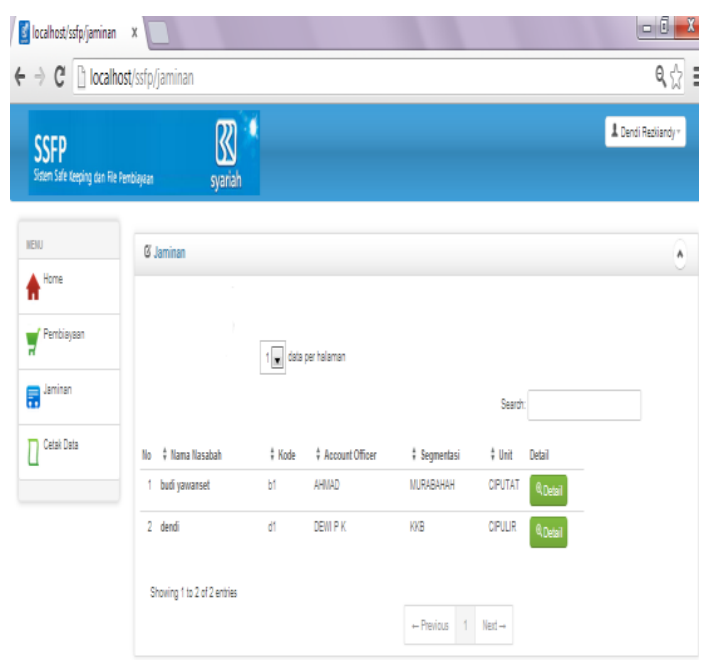

Gambar 12. Menu Jaminan pada Account Financing Support Manager

\section{KESIMPULAN}

Berdasarkan uraian dan pembahasan sebelumnya, maka dapat ditarik simpulan bahwa:

1) Sistem informasi safe keeping/jaminan dan pembiayaan dapat membantu memudahkan Bagian Custody dalam mengelola data safe keeping dan pembiayaan serta Financing Support Manager dalam melihat dan mencetak informasi Safe Keeping/Jaminan dan pembiayaan di BRI Syariah Kantor Cabang BSD City. 
2) Dengan adanya sistem informasi Safe Keeping/Jaminan dan file pembiayaan dapat meminimal risiko bank dari data yang tersimpan tidak akurat dan sesuai dengan fisik dokumen hukum jaminan dan pembiayaan yang ada di brankas bank.

\section{DAFTAR PUSTAKA}

1) HM, Jogiyanto. 2005. Analisis \& Desain SIstem Informasi : Pendekatan Terstruktur Teori dan Praktek Aplikasi Bisnis. Yogyakarta: Andi.

2) Kendall, Systems Analysis and Design seventh edition, Pearson International Edition, New Jersey, 2008.

3) Munawar, Pemodelan Visual dengan UML, Graha Ilmu, 2005

4) Suhendar, A dan Hariman Gunadi, Visual Modelling Menggunakan UML dan Rational Rose, Informatika, 2002.

5) Whitten, Jeffrey L. 2004. Systems Analysis \& Design Methods: Sixth Edition. New York: McGraw-Hill. 